ИНФОРМАЦИОННОЕ ПРОСТРАНСТВО. МЕДИАСРЕДА INFORMATION SPACE. MEDIA ENVIRONMENT

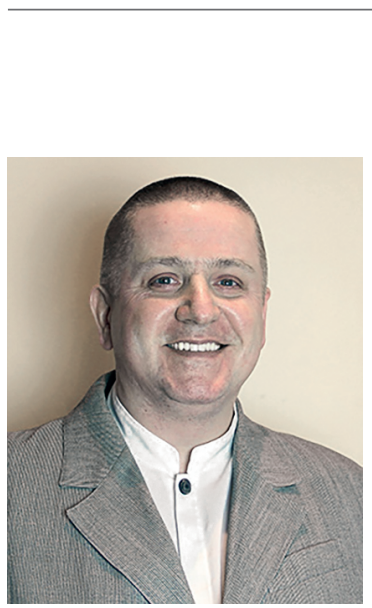

УДк 070(470+4)

DOI 10.17150/2308-6203.2021.10(1).109-129

\author{
Кремез Михаил \\ Докторант по специальности медиа \\ и коммуникация \\ Институт социальных наук, Тартуский университет, \\ Тарту, Эстония, e-mail: mihhail.kremez@ut.ee
}

Mihhail Kremez

PhD Student in Media and Communication

Institute of Social Studies, University of Tartu,

Tartu, Estonia, e-mail: mihhail.kremez@ut.ee

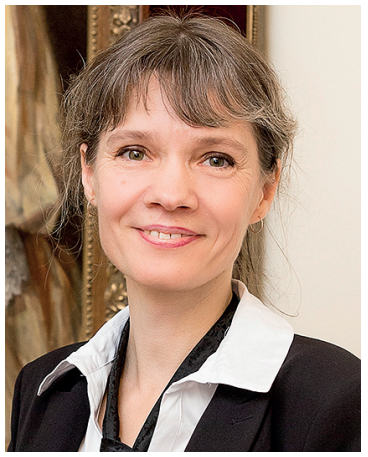

\title{
Кыутс-Клемм Рагне
}

Доктор фрилософии по специальности медиа и

коммуникация, заместитель директора института по науке и развитию, доцент социологии журналистики

Институт социальных наук, Тартуский университет, Тарту, Эстония, e-mail: ragne.kouts@ut.ee

\section{Ragne Kõuts-Klemm}

$\mathrm{PhD}$ in Media and Communication, Deputy Head of Research and Development, Associate Professor in Sociology of Journalism Institute of the Social Studies, University of Tartu, Tartu, Estonia, e-mail: ragne.kouts@ut.ee

\section{Фрейминг России в интернет-СМИ Эстонии, Германии и Болгарии: освещение двух конкретных событий}

Введение. Реальность социально конструируема, а СМИ играют активную роль в ее конструировании. То, как они конструируют реальность, зависит от производителей контента СМИ, т.е. журналистов.

Журналисты должны предоставлять как можно более разностороннюю и взвешенную картину события, но на них влияют различные внутренние и внешние факторы: их собственные убеждения; социальные нормы и ценности, идеологические и политические ориентации; стереотипы; политика и др.

Названные факторы могут быть причинами для использования фрейминга, включая использование фреймов, которые формируют, изменяют или дефрормируют мнение читателей о субъекте, например, о государстве.

При этом создателями фреймов могут быть не только журналисты. Они могут играть роль актора или посредника для фреймов других акторов, например, партий или организаций, аудиторий.

Цель обнаружения и описания медийных фреймов - показать ограничения в конструировании зарубежных событий в журналистской рабо- 
те. В частности, сравнение освещения в СМИ двух российских событий позволяет выявить сходства и различия в конструкциях зарубежных событий в информационной сфере ЕС.

Метод. Авторы применили метод квалитативного текстового анализа. Они сфокусировали внимание на семантических фрреймах в заголовках новостей, подзаголовках и основных текстах, включая эмоциональные и оценочные слова. Рамочный анализ - метод для анализа содержания новостей, который проводится в тесной связи с текстами и их контекстами, т.е. при анализе каждого фрейма рассматривался также контекст.

Акцент в исследовании сделан на самых популярных новостных порталах Эстонии (ERR, DELFI, Postimees, Õhtuleht). Порталы Германии (Deutsche Welle) и Болгарии (News.bg) выбраны для сравнения с интернет-СМИ Эстонии, чтобы найти общие черты и/или различия во фррейминге в связи с доминирующими и менее заметными фреймами. Поскольку исторические, культурные и экономические связи России с Эстонией, Германией и Болгарией различаются, авторы предположили, что освещение России в СМИ этих стран может также различаться.

Для рамочного анализа были отобраны статьи, посвященные двум событиям, которые различаются по охвату и характеру (чтобы определить повторяющиеся фреймы) и которые представляют интерес для стран-соседей и мира в целом: взрыв в Архангельской области 8 августа 2019 г. (далее «Взрыв») и Восточный экономический фрорум во Владивостоке с 4 по 6 сентября 2019 г. (далее «Форум»).

Результаты. Доминирующие фреймы в статьях о Взрыве:

1. Фрейм «Сокрытие правды», утверждающий, что российские власти скрывают информацию, особенно при инцидентах с оружием.

2. Фрейм «Беспорядок в стране», видящий Россию как «33 несчастья», где царит беспорядок в государстве и/или в отдельных сфрерах жизни.

3. Фрейм «Ядерная угроза», утверждающий, что Россия опасна изза своих атомных проектов, что часто ассоциируется с катастрофой в Чернобыле.

Менее заметные фрреймы:

1. Фрейм «Путин как магнит», уравнивающий Путина с Россией и наоборот, акцентируя внимание на магнетизме персоналии Путина для новостей - привлечение читателей фрамилией Путина в заголовке.

2. Фрейм «Ненужная гонка вооружений», оперирующий аргументами, что разработка новых видов оружия России не нужна.

3. Фрейм «Поиски виноватого», демонстрирующий активные поиски виноватого в России, которые оканчиваются нелепыми выводами.

4. Фрейм о «Конфрликтной России», отражающий разногласия между странами.

5. Фрейм «Государство не заботится о своих людях», демонстрирующий равнодушие государства к гражданам.

Авторы отмечают, что у порталов нет фактических знаний о Взрыве, и конструкции о событии тоже не добавляют ясности для читателей.

Внимание аудитории в новостях о Форуме привлекалось известностью участников. Поэтому фрейм «Путин как магнит» был доминирующим. Однако были использованы и другие:

1. «Наклеивание ярлыков» - наложение на кого-либо образа из своего убеждения, с выбором стороны в политическом смысле. 
2. «Плохой парень» - Россия как внешнеполитический игрок, с которым не хотят вести дело.

3. «Насилие» - власти РФ используют бессмысленное насилие против протестующих.

Журналисты реже являются авторами фрреймов, особенно если основная информация, как следует из анализа, поступает из агентств новостей (в том числе информация российских организаций) или международных медиаканалов, а также из российских СМИ (в том числе оппозиционных).

Заключение. Анализ демонстрирует наличие фреймов о России на всех изученных порталах (меньше на Deutsche Welle) и позволяет увидеть некоторые паттерны в трактовке российских событий новостными СМИ Эстонии, Германии и Болгарии. Авторы выяснили, что некоторые фрреймы широко использовались при конструировании обоих событий. Доминирующими были: «Путин как магнит», «Сокрытие правды», «Беспорядок в стране» и «Ядерная угроза».

Поскольку фреймы были аналитически выделены из освещения двух конкретных событий, их следует трактовать с осторожностью. Они не репрезентативны в отношении всех событий в России. Для обобщений потребуется дальнейший анализ. Однако выявленные фреймы можно использовать как основу для выстраивания более детальных классификаций.

Ключевые слова. Социальный конструкционизм, новостной портал, журналистика.

Информация о статье. Дата поступления 22 января 2021 г.; дата принятия к печати 12 февраля 2021 г.; дата онлайн-размещения 24 марта 2021 г.

\section{Framing Russia in the Estonian, German, and Bulgarian Online Media: Coverage of Two Concrete Events}

\footnotetext{
Abstract. The article provides a short theoretical discussion of framing in news and its role in the construction of reality. They present their approach to frame analysis by showcasing the coverage of two concrete events (the explosion in Arkhangelsk Oblast on August 8, 2019; the Eastern Economic Forum, that took place in Vladivostok on 4-6 September 2019) in Russia by the Estonian, German, and Bulgarian online media, with an emphasis on the Estonian news portals. The analysis rests on the assumption that individual members of society base their actions on the meanings that different events have to them; thus, an analysis of media constructions can explain people's attitudes to specific social phenomena. Journalists play a crucial role in the formation of public attitudes towards the events that take place outside the country borders.

Journalistic framing is based on the choices journalists make guided by their professional standards. It is demonstrated that the journalists working for the news portals under discussion generally use a rather narrow scope of frames in picturing Russia. On the one hand, these frames indicate limited access to information, while on the other hand, the use of frames by the journalists indicates their intention to attract the readership's attention, the need to present the reality in a simplified and easily understandable form, etc.
} 
The authors concluded that their findings indicate certain trends in framing Russia in the traditional EU online media, and argue for the necessity to pay more attention to the selection of information in online media newsrooms.

Keywords. Social constructionism, news portal, journalism.

Article info. Received January 22, 2021; accepted February 12, 2021; available online March 24, 2021.

\section{Introduction}

According to the theory of social constructionism, reality is socially constructed [1]. The media play an active role in the process, which can be compared with other sources of social reality [2, p. 34-35]. However, "mass media do not provide accurate information to create a realistic picture" [3, p. 151] and "cannot be considered as a neutral intermediary between the event and the observer, between the creators and consumers" [4, p. 74]. The way the media construct reality obviously depends on the producers of the media content i.e., journalists.

News journalists should use relevant and verified information sources and select what to publish and disseminate from the information inflow (press releases, news from news agencies, etc.) in compliance with the standards and ethics of professional journalism ${ }^{1}$ (see also [5]).

At the same time, journalists are influenced by various internal and external factors:

- their own beliefs [6, p. 74];

- social norms and values, ideological or political affiliations [7];

- stereotypes [8, p. 17; 9];

- the political factor that may influence the selection of frames in some cases, where a journalist loyal to the government or government-controlled media has to adapt to the interests of the state and its leaders [10];

${ }^{1}$ Communication Studies: Journalism Ethics and Standards // University of Washington Libraries. URL: https://guides.lib.uw.edu/research/commstudies/ethics.
- self-censorship [11, p. 12] and tacit censorship [12] related to the political factor indicated above;

- market pressure for journalists of privately owned media e.g., click-bate news headlines [13; 14];

- organizational pressures and constraints, journalistic routines [7], lack of time (especially in online media) [15, p. 51] and other resources [16];

- desire to reduce the complexity of reality to make it easily explainable by framing [17], so that journalists can use the frames that are well-known both to them and to their readership as regular templates, without a need to create additional content for producing news;

- professional and personal characteristics of the communicator (in our case, the journalist), including his or her perceptions of objectivity and understanding of professional aims and tasks, common and professional "rules of the game", his or her professional story, etc. [18].

The above-listed factors impact the outcomes of journalists' everyday work. These factors may be the reasons for the use of emotional and imprecise vocabulary, use of vague words for unreliable news sources, and framing [19], including the use of frames that form, transform or deform the opinion of the readers on the subject, for example, a country [20, p. 62]. In such cases, the media play an important role in how the news is interpreted by using rational and manipulative technologies - and both are realized by using frames [21, p. 414]. 
There are many different approaches in explaining the meanings of to frame, a frame, framing and frame/ framing analysis (for a review, see: Bodrunova [17], Franzosi \& Vicari [22], Kazakov [10], Matthes [23], inter alia). We use Entman's classic definition of framing that essentially involves selection and salience: "to frame is to select some aspects of a perceived reality and make them more salient in a communicating text, in such a way as to promote a particular problem definition, causal interpretation, moral evaluation, and/or treatment recommendation for the item described" [24, p. 52] (emphasis in original). It means that when certain aspects of an event are presented, other aspects may be ignored; several characteristics of an event remain hidden or will be removed from the construction. Entman claims that frames define problems, diagnose causes, make moral judgments, and suggest solutions [ibid.]. Framing is the concept that asserts the presence of elements in media text(s) that form the frame of perception and interpretation [25]. A frame is the form in which reality is presented by the media. Hence, any frame initially carries not only the imprint of subjective perception of reality, it may also possess some manipulative potential and be used to manipulate the opinions of the audience [10, p. $87 ; 20$, p. 61]. Frames could be identified by the methods at the intersection of psychology, cognitive science, and linguistics, but the existence of frames and their behavioral effects could have political influence [17, p. 128]. News frames carrying an inherent valence - emphasizing positive or negative aspects of an issue - have the ability to influence public support for policies [26]. Hence, news frames [27] can be positive or negative [28], in addition to many other options.
Journalists are not the only creators of media frames, since in a specific country the media can play the role of an agent or a mere mediator of other agents' frames [21, p. 409]. Hence, there is a difference between framing through media and framing by media [29]. Frames can be created by strategic communicators (political parties, organizations), journalists, and audiences [20, p. 60]. A journalist can play the role of conduit for the source's frame (frame-sender) or the role of the agent responsible for frame selection (frame-setter) [30]. E.g., German, Estonian, and Bulgarian journalists represent different journalistic cultures, and while German and Estonian journalists have acquired an accommodative role in society, according to the study of journalistic cultures around the globe [31], the role of Bulgarian journalists is interventionist-monitorial.

Media framing is like a "dynamic process driven by the journalistic dealings with sources and news values" [32]. Hence, framing in the media allows the journalist to interpret news information according to his or her plan [33, p. 44], whereas journalistic selections, especially when it comes to foreign news, depend heavily on the availability of information from international press agencies or on personal international contacts journalists have. Frames are informed by and, to some extent, subordinated to the social structures that govern the journalistic profession [34, p. 96]. When journalists possess great social and cultural capital, it enables wide use of different sources, including posts by bloggers and social media users, and access to powerful and culturally distinct sources in foreign countries.

We see that the above-mentioned factors may influence the use of fram- 
ing by journalists. Published frames may conflict with journalism ethics and standards, because they may have ideological and political influence on audiences in the interests of stakeholders - the government of the journalist's state, other states, politicians, business elites, etc. Hence, the aim of detecting and describing media frames is to show the limits of constructing foreign events in journalistic work. More specifically, the comparisons of media coverage of two events in Russia enables us to emphasize the commonalities and differences in the construction of foreign events in the European infosphere.

\section{Method}

In our research, we have used the method of qualitative textual analysis. We focus on the semantic frames in the news headlines, subheadlines, and body texts, including emotional and evaluative words, etc. Frame analysis is a method of analyzing the news content, and it will be developed in tight connection to the texts and their contexts [35, p. 149]. While analyzing each frame, we considered it as a whole (in the context), taking into account all the agents, activities, highlighted problems and proposed solutions involved. We detected who are these agents and how are they labeled, what the problem is and how it is presented in the article.

The focus of our research was on the Estonian news portals, based on the assumption that, being a close neighbor with a significant Russianspeaking population, the country's treatment of events in Russia could be somewhat more sophisticated. The Estonian information space is integrated with the European information space; thus, the German and Bulgarian news portals were selected for comparison with the Estonian online media in order to see if there were common trends and/or differences in framing in the EU online media in the case of both dominant and less visible frames.

For data collection, four most popular Estonian news portals were selected: the public service media $E R R^{2}$ (we analyzed the Estonian language publications; there are also English and Russian versions); a private news portal, DELFI (in the Estonian language; there are also English and Russian versions) ${ }^{3}$; the news website of the oldest Estonian newspaper, Postimees (in the Estonian language; there is also a Russian version) ${ }^{4}$; and the news portal of the Estonian tabloid newspaper Õhtuleht ${ }^{5}$.

For comparison, the study also included the Russian version of the German news portal Deutsche Welle (DW), dw.com ${ }^{6}$ (it has 30 versions in different languages), and the Bulgarian news portal News.bg, part of the Web Media Group $A D^{7}$.

${ }^{2}$ In Estonian Eesti Rahvusringhääling (ERR) : official information about Estonian Broadcasting. URL: https://news.err.ee/584393/about-err-newsstaff-and-contacts; Estonian Public Broadcasting Act // Riigi Teataja. URL: https://www.riigiteataja. ee/en/compare_original/530102013075; funded from the state budget, have incomes and other funding sources (see paragraph 7, (5), 1).

${ }^{3}$ Ekspress Media. URL: https://www.exm. ee/tegevusalad/veebimeedia/delfi/.

${ }^{4}$ Postimees Group. URL: https://www. postimeesgrupp.ee/about-us.

${ }^{5}$ Õhtuleht Kirjastus. URL: https://www. ohtulehtkirjastus.ee.

${ }^{6} \mathrm{~A}$ part of the same name "Germany's international broadcaster", "regulated by public law and financed by federal tax revenue" // DW. URL: https://www.dw.com/en/germanys-international-broadcaster/a-15703993.

${ }^{7}$ Web Media Group. URL: https://wmg.bg/ projects. 
As Estonia, Germany, and Bulgaria have different historical, cultural, and economic relations with Russia, we hypothesized that framing Russia by the media of these countries may also be different.

We chose two specific events which are of interest to the neighbouring countries and the world at large. The aim was to select events that are different in scope and nature, in order to identify recurring frames. These events are:

1. The explosion in Arkhangelsk Oblast on August 8, 2019 (hereinafter "the Explosion").

According to the official statement of the Ministry of Defense of the Russian Federation, there was an explosion followed by fire during a test of a liquid propellant jet engine at the military test site in Arkhangelsk Oblast, and there was no increase in the usual levels of radiation?.

Five men died on site and two died later from the consequences of acute radiation sickness as reported by some media channels (the total of five scientists and two military personnel), six were injured ${ }^{10}$.

${ }^{8}$ От скачка радиации до наград медикам: всё про инцидент у Нёноксы. Год спустя // 29.ru. URL: https://29.ru/text/world/2020/ 08/07/69408802/\#card_26.

${ }^{9}$ Два человека погибли при испытании реактивного двигателя под Архангельском // Интерфакс. URL: https://www.interfax. ru/russia/672041; Russia: 2 dead, 4 injured by rocket explosion at navy nuke base // Military Times. URL: https://www.militarytimes.com/ news/your-navy/2019/08/08/russia-2-dead-4injured-by-rocket-explosion-at-navy-nuke-base.

${ }^{10} \mathrm{Ha}$ полигоне в Архангельской области погибли сотрудники Росатома и Минобороны // Интерфакс. URL: https://www. interfax.ru/russia/672243; «Короткоживущие техногенные радионуклиды». Росгидромет подтвердил появление сразу трёх радио-
According to Rosatom (State Atomic Energy Corporation of the Russian Federation), its engineering and technical team had been working on the "isotope power source" for the propulsion system"1.

In Severodvinsk, $30 \mathrm{~km}$ away from the site of the explosion, a short-term increase of the radiation level was detected from 11:50 to 12:20 Moscow time (to $2 \mathrm{mSv} / \mathrm{h}$ - with the normal level of 0.11 $\mathrm{mSv} / \mathrm{h}$ ), but, according to a representative of Severodvinsk Administration, it posed no danger to health ${ }^{12}$ [36; 37].

Entries to port were banned for a month [38] and prolonged many times [39].

As can be seen from the references above, the event received a lot of coverage in the neighboring countries' media (for instance, Norway detected an increase of radiation level in Russia) and in the international media because of its potential impact. US Officials and some experts suspected that the explosion was connected to the testing of the new Russian rocket 9M730 Burevestnik (SSC-X-9 Skyfall, by NATO classification ${ }^{13}[40]$.

активных изотопов в атмосфрере после ЧП в Белом море // Фонтанка.py. URL: https:// www.fontanka.ru/2019/08/26/019; СМИ: двое пострадавших при взрыве в Архангельской области умерли не от травм, а от радиации // Коммерсантъ. URL: https://www.kommersant. ru/doc/4075000.

${ }^{11}$ Official statement of Rosatom on its site // Rosatom. URL: https://www.rosatom.ru/journalist/news/zayavlenie-departamenta-kommunikatsiy-goskorporatsii-rosatom/.

12 Official statement of Greenpeace Russia on its site. URL: https://greenpeace.ru/ news/2019/08/08/greenpeace-trebuet-proverki-skachka-radiacionnogo-fona-v-arhangelskoj-oblasti.

${ }^{13}$ Trump says US learning from Russia nuclear missile test blast // The Time of Israel. 2019. URL: https://www.timesofisrael.com/trump-saysus-learning-from-russia-nuclear-missile-test-blast. 
2. The Eastern Economic Forum (hereinafter "the Forum"), aiming to find more investors for the Russian Far East, took place in Vladivostok between the $4^{\text {th }}$ and the $6^{\text {th }}$ of September 2019 and hosted over 8,500 participants from 65 countries $^{14}$. The key event of the business program took place on 5 September: a plenary session of the Forum featured Vladimir Putin, the President of the Russian Federation, Shinzō Abe, the Prime Minister of Japan, Narendra Modi, the Prime Minister of India, Mahathir Bin Mohamad, the Prime Minister of Malaysia, and Khaltmaagiin Battulga, the President of Mongolia ${ }^{15}$.

\section{Findings}

During the analyzed period, the selected news portals published 123 articles about the Explosion and the Forum (Table 1 ). The latter received sig-

${ }^{14}$ Eastern Economic Forum. URL: https:// forumvostok.ru/en/archive/2019/outcomes-ofthe-eef-2019.

${ }^{15}$ LIVE: Putin, Modi, Abe and other leaders participate in Eastern Economic Forum plenary session // Youtube. 2019. URL: https://youtu.be/ SFvSoGdfzmE. nificantly less attention from the media, whereas the former got almost equal attention from all the news portals (except the tabloid news portal Õhtuleht). Most of the articles were news-style publications. Some were opinions of observers or interviews with experts, but even these included news components.

The publication dynamics show that the Explosion was being covered over a longer period of time, from August to November, while the Forum only during the particular days of the event in September (see Figures 1 and 2).

The frames of Russia were analyzed in all these texts. A frame was operationalized as a coherent view on Russia's actions, characteristics, aims and relations to others. Each detected frame was categorized by the basic meaning and described in detail for better understanding, with examples from the articles. We tried to find the salience of frame in the headlines, leads, body texts that are published for the "promoting a particular problem definition, causal interpretation, moral evaluation, and/or treatment recommendation" [24, p. 52]. Our aim was to detect the presence of elements in the media texts

Table 1

\section{Number of articles about the selected cases in the sample. News portals are listed in the order presented above}

\begin{tabular}{|l|r|r|r|}
\hline \multicolumn{1}{|c|}{ News portal } & \multicolumn{1}{c|}{$\begin{array}{c}\text { Articles } \\
\text { about the Explosion }\end{array}$} & $\begin{array}{c}\text { Articles } \\
\text { about the Forum }\end{array}$ & \multicolumn{2}{c|}{ Total } \\
\hline ERR & 16 & 2 & 18 \\
\hline DELFI & 13 & 3 & 16 \\
\hline Postimees & 25 & 4 & 29 \\
\hline Õhtuleht & 5 & 1 & 6 \\
\hline DW & 21 & 7 & 28 \\
\hline News.bg & 22 & 4 & 26 \\
\hline Total & 102 & 21 & 123 \\
\hline
\end{tabular}



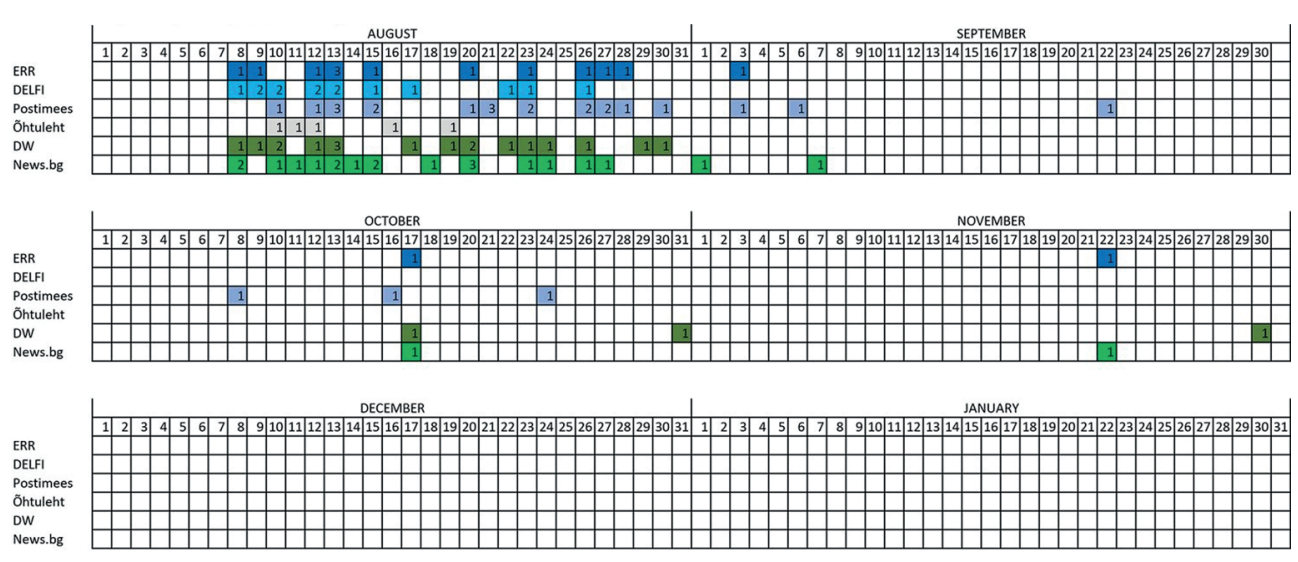

Figure 1. Number of articles about the Explosion by the news portals during the analyzed period

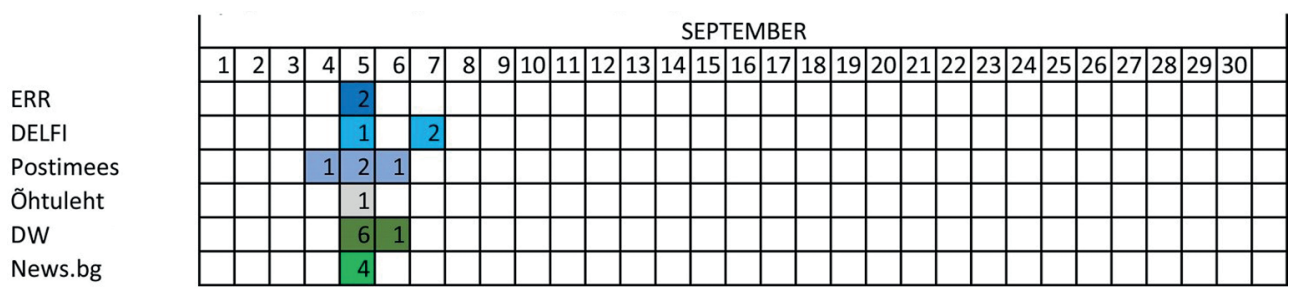

Figure 2. Number of articles about the Forum by the news portals during the analyzed period

that form the frame of perception and interpretation [25]. We also focused on the elements of the news that emphasize positive or negative aspects of an issue [26]. These are thematic and stylistically colored vocabulary, stylistic techniques based on a pragmatically motivated deviation from the linguistic norm and its stylistically neutral version, [20, p. 61], clickbait headlines [13; 14], tropes and figures [22] in the news, etc. Very often the headlines of the articles summarized the core elements of a particular frame - in such cases the article headlines are given as simplifying examples of frames.

The body of articles about the Explosion was rich with different frames (see Appendix). Nevertheless, some of them appeared dominant while others did not. The predominant treatment of Russia in relation to the Explosion constructed the event as "Hiding the truth", "Disorder in the country" (or simply "Disorder"), or through the lens of the "Nuclear threat".

The frame "Hiding the truth" claims that authorities of the Russian Federation try to hide some or many facts every time, especially in the context of incidents with weapons. This frame is mostly negative when journalists need more exact information about the situation. Also, they can use it for clickbaiting [13; 14] solely with such words as "mysterious explosion", "mysterious accident". Certainly, hiding information by the authorities always attracts read- 
ers. The clearest example of this frame can be found in the News.bg headline referring to the other media:

Novaya Gazeta: There are 7 victims in Arkhangelsk, the authorities are hiding information ${ }^{16}$

News.bg, probably, showed the source (Russian newspaper in opposition to the government) in the headline for two reasons: they did not have access to the original information from the authorities and other agents that participated in the event, and the mediation of other media texts allowed them to avoid responsibility for the framing of the event.

The frame "Disorder in the country" shows Russia as the master of disaster, because disorder rules in the state and/ or in various spheres of life. This frame, by definition, has a negative connotation. Disorder in Russia is an oftenused stereotype in the news media. Accidents may happen in any country with a large stock of weapons and complex military technologies. Again, an example can be found in the headline of an article in the "yellow news" portal Õhtuleht. The article is very expressive:

ACCIDENT AFTER ACCIDENT: Seven people died at a Russian naval training ground [41]

Two other accidents, on July 1 and August 5, are mentioned in the text, but they are not in the DELFI portal's article with the same frame in the headline:

In Arkhangelsk another Russian military object caught fire, two people died [42]

The third dominant frame used for describing Russia with reference to

${ }^{16}$ «Новая газета»: Жертвите в Архангелск са 7, властите крият информация // News.bg. URL: https://news.bg/world/novayagazeta-zhertvite-v-arhangelsk-sa-7-vlastitekriyat-informatsiya.html. the Explosion, is the frame "Nuclear threat": Russia is dangerous because of its nuclear projects often associated with the nuclear disaster in Chernobyl in 1986 in the USSR. By deliberately exaggerating the danger, journalists often aim to scare the readership by the headlines and body texts. These are usually clickbating solutions. Consider the following example:

Rosgidromet reported 16 times increase of radiation in Severodvinsk [43]

It was explained in the article that the increase was "4-16 times"; however, it was not dangerous for people [44]. The same frame was used by some other news portals.

Less visible frames in the articles about the Explosion were the frames "Putin as a magnet", "Needless arms race"; or even less often the constructions about "Blame game", "Conflicting Russia", and the frame that claims that "The state doesn't care about its people".

The frame "Putin as a magnet" likens Putin to Russia and vice versa. This frame is very close to the human interest frame presented by Semetko and Valkenburg [45], when the accent is on the magnetism of Putin's personality as a news magnet for foreign journalists - if this name is in the headline, the site visitors are more likely to read the article. The frame could be positive, neutral or negative depending on the context.

It is worthy of note that the frame "Putin as a magnet" was the dominant frame in the case of the Forum. Many headlines opened with the name of the President of the Russian Federation. Vladimir Putin was considered the main newsmaker of the Forum; he commented on many different issues (not solely related to the Forum) that caught the attention of the news portals 
analyzed in our study: the peace treaty between Japan and Russia, the exchange of prisoners between Ukraine and Russia, youth protests in Russia, etc. Totally, 14 out of the 21 analyzed articles that covered the Forum had Putin's name in the headlines, e.g.,

According to Putin, Russia would welcome restoration of the $\mathrm{G} 8$ [46]

Putin: Negotiations on a large-scale Russian-Ukrainian prisoner exchange are nearing completion [47]

Putin tried to sell hypersonic missiles to Trump ${ }^{17}$

PUTIN: The exchange of prisoners with Ukraine will be large-scale [48]

Putin announced the imminent exchange of prisoners between the Russian Federation and Ukraine [49]

Putin: Russia and China coordinate international affairs ${ }^{18}$

The frame "Needless arms race" in an article about the Explosion combines the arguments that the development of new weapons by Russia is needless. Here is an example from the headline:

Explosion near Severodvinsk: "Why is the Burevestnik needed at all?" [50]

The interviewed expert thinks that this arms race is needless, that this is the wrong direction to take.

The frame "Blame game" deals with the intensive search for the guilty by Russia that ends up with nonsensical conclusions. This frame carries a negative connotation or is used as satire in clickbait headlines [14; 15]. Con-

${ }^{17}$ Putin üritas Trumpile hüpersoonilisi rakette müüa // Postimees. URL: https://maailm. postimees.ee/6771386/putin-uritas-trumpilehupersoonilisi-rakette-muua.

18 Путин: Русия и Китай координират международните си позиции // News.bg. URL: https://news.bg/world/putin-rusiya-i-kitaykoordinirat-mezhdunarodnite-si-pozitsii.html. sider the following headline from the Estonian news website Postimees:

Russian officials blame the radiation on Fukushima crabs ${ }^{19}$

The news source for this headline frame was CNN [51], but the Estonian version was more satirical, and an "illustrative" picture of a crab was added. As a matter of fact, only one sample had Cesium 137 in its muscular tissue after the tests had been taken, and the specialists who ran the tests suspected that Cesium 137 might have come from bad sea food.

The frame "Conflicting Russia" reflects disagreement between countries:

Russia has blamed the United States for a failed missile test near Severodvinsk ${ }^{20}$

In fact, Russian official Karpov blamed the US not for the failed test but rather for "unilateral withdrawal from the Treaty on the limitation of missile defense systems in 2002". Thus, conflict frames in the news may be also the result of active journalistic intervention in the frame-building process [52].

Another frame in the articles about the Explosion appeared only once and had a negative connotation: "The state does not care about its people":

The accident of the "special unit" at the test site in the Arkhangelsk Oblast showed that the Russians are still heroes, but for the state they are cannon fodder, Ivan Preobrazhensky believes [53] (emphasis added).

${ }^{19}$ Venemaa ametnikud süüdistavad kiirguses Fukushima krabisid // Postimees. URL: https://maailm.postimees.ee/6761961/venemaa-ametnikud-suudistavad-kiirguses-fukushima-krabisid.

${ }^{20}$ Русия обвини САЩ за неуспешния ракетен опит край Северодвинск // News. bg. URL: https://news.bg/world/rusiya-obvinisasht-za-neuspeshniya-raketen-opit-krayseverodvinsk.html. 
DW informs readers that: "The comment expresses the personal opinion of the author. It may not coincide with the opinion of the Russian edition and Deutsche Welle in general". This article also has other frames: "Hiding the truth", "Disorder" and "Putin as a magnet".

Summarizing the frames used in the articles about the explosion in Arkhangelsk Oblast on August 8, we can conclude that the media did not have factual knowledge about what was happening, neither did the constructions of the event add clarity for the readership.

As compared to the Explosion, the September 2019 Forum was an event of a different type. Its coverage was coherent, it lasted for a short period of time in the media news flow, and it did not have any dramatic aspects. The readership's attention was secured by the particular criteria for newsworthiness - the prominence of the Forum participants. Thus, the frame "Putin as a magnet" was dominant to the extent that it almost hid all other frames in the articles. Nevertheless, the other frames used in relation to that event were "Label-sticking", "Bad boy", and "Violence".

The frame "Label-sticking" is used when anybody is named with evaluative words, labeling him or her according to the journalist's own belief [6, p. 74] or opinion by choosing a side in the political sense [10], for example:

Video: In Russia, exchanged prisoners carried their bags themselves, in Ukraine they were received as national heroes $^{21}$

${ }^{21}$ VIDEO | Venemaal tassisid vahetatud vangid oma kotte ise, Ukrainas võeti nad vastu rahvakangelastena // DELFI. URL: https:// www.delfi.ee/news/paevauudised/valismaa/ video-venemaal-tassisid-vahetatud-vangid-
The original headline in the news source, RTVI, is neutral and gives the readership an opportunity to think:

Watch how the exchanged prisoners were met in Moscow and Kiev22

The frame "Bad boy" pictures Russia as a bad boy with whom nobody wants to have any business. This frame carries a negative connotation. Consider the following example from the body text of an article:

After the annexation of the Crimea other members of the union threw away Russia from G8 and renamed it the G7 under the pandering of the US President Barack Obama (emphasis added) [54].

Naming the annexation of the Crimea as such can indicate the ideological or political orientations of the journalists [7], because the official statement of Estonia and the EU is that the Crimea was annexed by Russia. Nevertheless, without knowing the opinion of particular journalists about the event, it can be interpreted as an example of self-censorship [11, p. 12] and/or tacit censorship [12].

Another frame found in the articles about the Forum is that of "Violence" Russian authorities use needless violence against the protesting people. This is a frame with a negative connotation, since it presents Russia as not supporting the basic human right to participate in political protests and demonstrations. When no reference to the source is given, it looks like fake news [55], because the reader should not have to seek out the source by himself. Consider the following example from the body text of an article:

oma-kotte-ise-ukrainas-voeti-nad-vasturahvakangelastena?id=87366521.

${ }^{22}$ RTVI Twitter. URL: https://twitter.com/ RTVi/status/1170303453412954112. 
OMON and Rosgvardia officers acted harshly, beating up activists and even bystanders [56].

No source is specified in the article, thus it leaves open the question about who created the frame and reproduced it in the media.

Usually, frames are connected to particular agents in the public field. Journalists, personally, are rarely the authors of frames, especially when key information comes from press agencies or from other international media channels. The articles analyzed in this study often use international ( $A F P, R e-$ uters, Bloomberg) and Russian news agencies, both state (TASS) and privately held (Interfax, Belomorkanal) as their sources. News portals usually get information from Russian organizations and authorities through news agencies. ERR and Postimees have often used the local press agency $B N S^{23}$ as a news source. BNS belongs to Postimees Group and cooperates with AFP and Interfax - that is why ERR and Postimees get information from them.

The international media like $B B C$ and $C N N$, and the Russian media, like The Moscow Times, a neutral Russian newspaper published in English or the oppositional Novaya Gazeta, are often used as sources. Also popular is the Meduza.io, an oppositional news portal based in Latvia; it was used both by the Estonian ERR and Postimees (two times), and the Bulgarian News.bg.

Thus, a frame may be created by the news sources - news agencies, international media or the Russian media (especially, the oppositional media), but may also be modified by the Estonian, German, and Bulgarian journalists

${ }^{23}$ Baltic News Service. URL: https://www. bns.ee/en. before publication, transforming from "frame-sender" to "frame-setter" [30].

$D W$ often uses its own resources, and News.bg used DW as its information source on one occasion.

\section{Conclusion}

The framing analysis allowed us to see some patterns in how events in Russia are covered by the Estonian and other European news media. As our analysis of two concrete events has shown, certain frames are widely used in their media construction. The most frequent frames are "Putin as a magnet", "Hiding the truth", "Disorder", and "Nuclear threat".

As the undertaken analysis has shown, certain frames about Russia were employed by all the news portals from our sample. Only the German public broadcaster's news portal had fewer frames than the articles in the Estonian or Bulgarian online media. $D W$, the German public broadcaster, had more original news about the events. This can be put down to the stronger position of $D W$ on the European media landscape, at least in comparison to the Estonian and Bulgarian media. DW has a broader network of news sources for getting information, access to high-ranking officials in the Russian Federation, and more general resources such as higher and stable financing and a bigger editorial board with qualified personnel, including Russian-speaking journalists.

There may be multiple reasons for the use of frames. On the one hand, it may be a need to simplify the complicated reality for the readership's sake and make particular events readily understandable. On the other hand, framing may be the result of journalistic work and everything that comes with it: the journalist's wish to attract the reader's attention 
by clickbait headlines (with commercial goals in mind) under market pressure conditions, organizational pressures and constraints, lack of time and other resources, his or her beliefs (including ideology), stereotypes, political preferences, self-censorship (tacit censorship), etc.

Our findings demonstrate certain framing trends related to Russia in the EU online media. Since these frames were analytically distilled from the media coverage of two specific events the explosion in Arkhangelsk Oblast on August 8, 2019, and the Economic Forum in Vladivostok in September
2019 , they should be treated with caution. They are not representative of the treatment received by all the various events that take place in Russia. Before any generalizations can be made, further thorough analysis of the frames used in the media is needed. However, the frames analyzed in the present study can be used as a solid basis for building a more detailed classification.

Another interesting venue for further research would be an analysis of information flows between media channels to bring us closer to answering the question, "Who is the creator of the frame?"

Frames and news sources in the analyzed articles

Appendix

\begin{tabular}{|c|c|c|c|c|c|c|}
\hline Link to article & $\begin{array}{l}\text { Media } \\
\text { channel }\end{array}$ & Frame(s) & Source 1 & Source 2 & Source 3 & Source 4 \\
\hline err.ee/970141 & ERR & $\begin{array}{l}\text { Hiding } \\
\text { the truth }\end{array}$ & Yle & $\begin{array}{l}\text { Bloom- } \\
\text { berg }\end{array}$ & $\begin{array}{l}\text { Rosgi- } \\
\text { dromet }\end{array}$ & ERR \\
\hline err.ee/970167 & ERR & $\begin{array}{l}\text { Hiding } \\
\text { the truth, } \\
\text { Putin as } \\
\text { a magnet }\end{array}$ & $\begin{array}{l}\text { Bloom- } \\
\text { berg }\end{array}$ & $\begin{array}{l}\text { Rosgi- } \\
\text { dromet }\end{array}$ & WNA & ERR \\
\hline err.ee/972168 & ERR & $\begin{array}{l}\text { Hiding } \\
\text { the truth }\end{array}$ & СТВTO & & & \\
\hline err.ee/975433 & ERR & $\begin{array}{l}\text { Hiding } \\
\text { the truth }\end{array}$ & CNBC & $\begin{array}{l}\text { USA intel- } \\
\text { ligence }\end{array}$ & RFE/RL & \\
\hline err.ee/976535 & ERR & Disorder & $\begin{array}{l}\text { Belo- } \\
\text { morka- } \\
\text { nal }\end{array}$ & Meduza.io & Greenpeace & $\begin{array}{l}\text { Rosgi- } \\
\text { dromet }\end{array}$ \\
\hline err.ee/1006044 & ERR & $\begin{array}{l}\text { Hiding } \\
\text { the truth }\end{array}$ & Reuters & BBC & Daily Mail & Rossia 24 \\
\hline err.ee/977475 & ERR & $\begin{array}{l}\text { Label- } \\
\text { sticking }\end{array}$ & BNS & AFP & $\begin{array}{l}\text { "Ukrainian } \\
\text { source" }\end{array}$ & $\begin{array}{l}\text { "Russian } \\
\text { and } \\
\text { Ukrainian } \\
\text { media" }\end{array}$ \\
\hline err.ee/977547 & ERR & $\begin{array}{l}\text { Bad boy, } \\
\text { Label- } \\
\text { sticking, } \\
\text { Putin as } \\
\text { a magnet }\end{array}$ & BNS & & & \\
\hline $\begin{array}{l}\text { delfi. } \\
\text { ee/87077675 }\end{array}$ & Delfi & Disorder & Interfax & TASS & $\begin{array}{l}\text { Russian } \\
\text { Ministry of } \\
\text { Defense }\end{array}$ & $\begin{array}{l}\text { Green- } \\
\text { peace }\end{array}$ \\
\hline
\end{tabular}


Вопросы теории и практики журналистики. 2021. Т. 10, № 1. С. 109-129

Continuation of the table

\begin{tabular}{|c|c|c|c|c|c|c|}
\hline Link to article & $\begin{array}{c}\text { Media } \\
\text { channel }\end{array}$ & Frame(s) & Source 1 & Source 2 & Source 3 & Source 4 \\
\hline $\begin{array}{l}\text { delfi. } \\
\text { ee/87157571 }\end{array}$ & Delfi & $\begin{array}{l}\text { Hiding } \\
\text { the truth }\end{array}$ & $\begin{array}{l}\text { The } \\
\text { Moscow } \\
\text { Times }\end{array}$ & DELFI & & \\
\hline $\begin{array}{l}\text { delfi. } \\
\text { ee/87206859 }\end{array}$ & Delfi & $\begin{array}{l}\text { Hiding } \\
\text { the truth }\end{array}$ & BBC & $\begin{array}{l}\text { Rosgi- } \\
\text { dromet }\end{array}$ & $\begin{array}{l}\text { Russian } \\
\text { Ministry of } \\
\text { Health }\end{array}$ & \\
\hline $\begin{array}{l}\text { delfi. } \\
\text { ee/87084755 }\end{array}$ & Delfi & $\begin{array}{l}\text { Nuclear } \\
\text { threat }\end{array}$ & 29.ru & $\begin{array}{l}\text { Adminis- } \\
\text { tration of } \\
\text { Severo- } \\
\text { dvinsk }\end{array}$ & $\begin{array}{l}\text { Russian } \\
\text { Ministry of } \\
\text { Defense }\end{array}$ & \\
\hline $\begin{array}{l}\text { delfi. } \\
\text { ee/87344871 }\end{array}$ & Delfi & $\begin{array}{l}\text { Putin as } \\
\text { a magnet }\end{array}$ & Unian & DELFI & & \\
\hline $\begin{array}{l}\text { delfi. } \\
\text { ee/87366521 }\end{array}$ & Delfi & \begin{tabular}{|l|} 
Label- \\
sticking
\end{tabular} & $\begin{array}{l}\text { RTVI } \\
\text { Twitter }\end{array}$ & AFP & $\begin{array}{l}\text { Anna } \\
\text { Islamova in } \\
\text { Facebook }\end{array}$ & \begin{tabular}{|l|} 
Attorney \\
Gen- \\
eral of \\
Ukraine, \\
Facebook \\
\end{tabular} \\
\hline $\begin{array}{l}\text { postimees. } \\
\text { ee/6752672 }\end{array}$ & $\begin{array}{l}\text { Posti- } \\
\text { mees }\end{array}$ & $\begin{array}{l}\text { Nuclear } \\
\text { threat }\end{array}$ & \begin{tabular}{|l|} 
Echo \\
Moskvy
\end{tabular} & PM & $\begin{array}{l}\text { Rosgi- } \\
\text { dromet }\end{array}$ & \\
\hline $\begin{array}{l}\text { postimees. } \\
\text { ee/6753724 }\end{array}$ & $\begin{array}{l}\text { Posti- } \\
\text { mees }\end{array}$ & $\begin{array}{l}\text { Hiding } \\
\text { the truth, } \\
\text { Disorder, } \\
\text { Nuclear } \\
\text { threat }\end{array}$ & $\begin{array}{l}\text { Bloom- } \\
\text { berg }\end{array}$ & \begin{tabular}{|l|} 
Russian \\
Ministry of \\
Defense \\
\end{tabular} & NYT & DNA \\
\hline $\begin{array}{l}\text { postimees. } \\
\text { ee/6758029 }\end{array}$ & $\begin{array}{l}\text { Posti- } \\
\text { mees }\end{array}$ & $\begin{array}{l}\text { Nuclear } \\
\text { threat }\end{array}$ & AFP & BNS & $\begin{array}{l}\text { The } \\
\text { Moscow } \\
\text { Times }\end{array}$ & CTBTO \\
\hline $\begin{array}{l}\text { postimees. } \\
\text { ee/6760117 }\end{array}$ & $\begin{array}{l}\text { Posti- } \\
\text { mees }\end{array}$ & $\begin{array}{l}\begin{array}{l}\text { Nuclear } \\
\text { threat }\end{array} \\
\end{array}$ & AFP & BNS & PM & \\
\hline $\begin{array}{l}\text { postimees. } \\
\text { ee/6761961 }\end{array}$ & $\begin{array}{l}\text { Posti- } \\
\text { mees }\end{array}$ & $\begin{array}{l}\text { Blame } \\
\text { game }\end{array}$ & CNN & PM & Meduza.io & BNS \\
\hline $\begin{array}{l}\text { postimees. } \\
\text { ee/6763260 }\end{array}$ & $\begin{array}{l}\text { Posti- } \\
\text { mees }\end{array}$ & $\begin{array}{l}\text { Nuclear } \\
\text { threat }\end{array}$ & Interfax & PM & $\begin{array}{l}\text { Rospotreb- } \\
\text { nadzor }\end{array}$ & \\
\hline $\begin{array}{l}\text { postimees. } \\
\text { ee/ } 6763467\end{array}$ & $\begin{array}{l}\text { Posti- } \\
\text { mees }\end{array}$ & $\begin{array}{l}\text { Hiding } \\
\text { the truth }\end{array}$ & $\begin{array}{l}\text { Meduza. } \\
\text { io } \\
\end{array}$ & \begin{tabular}{|l|} 
Business \\
Insider
\end{tabular} & \begin{tabular}{|l|} 
Rosgid- \\
romet
\end{tabular} & \\
\hline $\begin{array}{l}\text { postimees. } \\
\text { ee/6768969 }\end{array}$ & $\begin{array}{l}\text { Posti- } \\
\text { mees }\end{array}$ & Disorder & $\begin{array}{l}\text { Novaya } \\
\text { Gazeta }\end{array}$ & $\begin{array}{l}\text { Belomor- } \\
\text { kanal }\end{array}$ & PM & \begin{tabular}{|l|} 
Russian \\
Ministry of \\
Defense \\
\end{tabular} \\
\hline $\begin{array}{l}\text { postimees. } \\
\text { ee/6769716 }\end{array}$ & $\begin{array}{l}\text { Posti- } \\
\text { mees }\end{array}$ & $\begin{array}{l}\text { Putin as } \\
\text { a magnet }\end{array}$ & AFP & BNS & Interfax & \\
\hline $\begin{array}{l}\text { postimees. } \\
\text { ee/6770672 }\end{array}$ & $\begin{array}{l}\text { Posti- } \\
\text { mees }\end{array}$ & $\begin{array}{l}\text { Putin as } \\
\text { a magnet }\end{array}$ & Interfax & BNS & & \\
\hline $\begin{array}{l}\text { postimees. } \\
\text { ee/6771005 }\end{array}$ & $\begin{array}{l}\text { Posti- } \\
\text { mees }\end{array}$ & $\begin{array}{l}\text { Putin as } \\
\text { a magnet }\end{array}$ & AFP & BNS & & \\
\hline
\end{tabular}


Theoretical and Practical Issues of Journalism, 2021, vol. 10, no. 1, pp. 109-129

Continuation of the table

\begin{tabular}{|c|c|c|c|c|c|c|}
\hline Link to article & $\begin{array}{l}\text { Media } \\
\text { channel }\end{array}$ & Frame(s) & Source 1 & Source 2 & Source 3 & Source 4 \\
\hline $\begin{array}{l}\text { postimees. } \\
\text { ee/6771386 }\end{array}$ & $\begin{array}{l}\text { Posti- } \\
\text { mees }\end{array}$ & $\begin{array}{l}\text { Putin as } \\
\text { a magnet }\end{array}$ & $\begin{array}{l}\text { News- } \\
\text { week }\end{array}$ & PM & & \\
\hline $\begin{array}{l}\text { ohtuleht. } \\
\text { ee/973039 }\end{array}$ & Õhtuleht & Disorder & TASS & Rosatom & \begin{tabular}{|l} 
Russian \\
Ministry of \\
Defense
\end{tabular} & $\begin{array}{l}\text { Adminis- } \\
\text { tration of } \\
\text { Severo- } \\
\text { dvinsk }\end{array}$ \\
\hline \begin{tabular}{|l} 
ohtuleht. \\
ee/973358
\end{tabular} & Õhtuleht & $\begin{array}{l}\text { Hiding } \\
\text { the truth }\end{array}$ & Baza & Rosatom & $\begin{array}{l}\text { Administra- } \\
\text { tion of } \\
\text { Severo- } \\
\text { dvinsk } \\
\end{array}$ & \begin{tabular}{|l|} 
Russian \\
Ministry of \\
Defense
\end{tabular} \\
\hline $\begin{array}{l}\text { ohtuleht. } \\
\text { ee/973826 }\end{array}$ & Õhtuleht & $\begin{array}{l}\text { Nuclear } \\
\text { threat }\end{array}$ & CNN & DNA & $\begin{array}{l}\text { Rosgi- } \\
\text { dromet }\end{array}$ & \\
\hline $\begin{array}{l}\text { ohtuleht. } \\
\text { ee/975866 }\end{array}$ & Õhtuleht & \begin{tabular}{|l} 
Putin as \\
a magnet
\end{tabular} & Unian & $\begin{array}{l}\text { Anna } \\
\text { Islamova } \\
\text { in } \\
\text { Facebook }\end{array}$ & "The media" & $\begin{array}{l}\text { Attorney } \\
\text { General of } \\
\text { Ukraine, } \\
\text { Facebook }\end{array}$ \\
\hline $\begin{array}{l}\text { https://p.dw.com/ } \\
\text { p/3Ngyo }\end{array}$ & DW & $\begin{array}{l}\text { Hiding } \\
\text { the truth }\end{array}$ & Reuters & \begin{tabular}{|l} 
Russian \\
Ministry of \\
Defense
\end{tabular} & $\begin{array}{l}\text { Adminis- } \\
\text { tration of } \\
\text { Severo- } \\
\text { dvinsk } \\
\end{array}$ & Rosatom \\
\hline $\begin{array}{l}\text { https://p.dw.com/ } \\
\text { p/3Nn3o }\end{array}$ & DW & \begin{tabular}{|l|} 
Hiding \\
the truth, \\
Disorder, \\
State \\
does not \\
care, Pu- \\
tin as a \\
magnet
\end{tabular} & DW & Rosatom & & \\
\hline $\begin{array}{l}\text { https://p.dw.com/ } \\
\text { p/3Np4k }\end{array}$ & DW & $\begin{array}{l}\text { Nuclear } \\
\text { threat }\end{array}$ & $\begin{array}{l}\text { Rosgi- } \\
\text { dromet }\end{array}$ & DW & & \\
\hline $\begin{array}{l}\text { https://p.dw.com/ } \\
\text { p/3O2HR }\end{array}$ & DW & \begin{tabular}{|l|} 
Needless \\
arms \\
race
\end{tabular} & DW & Rosatom & \begin{tabular}{|l|} 
Donald \\
Trump \\
Twitter
\end{tabular} & \\
\hline $\begin{array}{l}\text { https://p.dw.com/ } \\
\text { p/3Oi7Y }\end{array}$ & DW & \begin{tabular}{|l|} 
Needless \\
arms race
\end{tabular} & DW & \begin{tabular}{|l} 
Russian \\
Ministry of \\
Defense
\end{tabular} & & \\
\hline $\begin{array}{l}\text { https://p.dw.com/ } \\
\text { p/3P2ev }\end{array}$ & DW & $\begin{array}{l}\text { Putin as } \\
\text { magnet }\end{array}$ & TASS & DW & $\begin{array}{l}\text { Administra- } \\
\text { tion of the } \\
\text { President of } \\
\text { Ukraine } \\
\end{array}$ & $\begin{array}{l}\text { Attorney } \\
\text { General of } \\
\text { Ukraine, } \\
\text { Facebook }\end{array}$ \\
\hline $\begin{array}{l}\text { https://p. } \\
\text { dw.com/p/3P4Ft }\end{array}$ & DW & $\begin{array}{l}\text { Putin as } \\
\text { a magnet }\end{array}$ & DW & & & \\
\hline $\begin{array}{l}\text { https://p.dw.com/ } \\
\text { p/3P50w }\end{array}$ & DW & \begin{tabular}{|l} 
Putin as a \\
magnet, \\
Violence
\end{tabular} & DW & & & \\
\hline
\end{tabular}


Вопросы теории и практики журналистики. 2021. Т. 10, № 1. С. 109-129

Continuation of the table

\begin{tabular}{|c|c|c|c|c|c|c|}
\hline Link to article & \begin{tabular}{|c|} 
Media \\
channel
\end{tabular} & Frame(s) & Source 1 & Source 2 & Source 3 & Source 4 \\
\hline $\begin{array}{l}\text { https://news. } \\
\text { bg/world/ } \\
\text { novaya-gazeta- } \\
\text { zhertvite-v- } \\
\text { arhangelsk-sa- } \\
\text { 7-vlastite-kriyat- } \\
\text { informatsiya. } \\
\text { html }\end{array}$ & News.bg & $\begin{array}{l}\text { Hiding } \\
\text { the truth }\end{array}$ & $\begin{array}{l}\text { Novaya } \\
\text { Gazeta }\end{array}$ & Newsader & Rosatom & $\begin{array}{l}\text { Source of } \\
\text { Newsader }\end{array}$ \\
\hline $\begin{array}{l}\text { https://news. } \\
\text { bg/world/ } \\
\text { tramp-sasht- } \\
\text { pritezhavat-po- } \\
\text { dobri-raketi- } \\
\text { ot-ruskiya- } \\
\text { burevestnik. } \\
\text { html }\end{array}$ & News.bg & $\begin{array}{l}\text { Nuclear } \\
\text { threat }\end{array}$ & News.bg & $\begin{array}{l}\text { Donald } \\
\text { Trump } \\
\text { Twitter }\end{array}$ & $\begin{array}{l}\text { "Russian } \\
\text { media" }\end{array}$ & \\
\hline $\begin{array}{l}\text { https://news. } \\
\text { bg/world/ } \\
\text { skrili-ot-lekarite- } \\
\text { v-arhangelsk- } \\
\text { che-im-vodyat- } \\
\text { oblacheni-s-ra- } \\
\text { diatsiya.html } \\
\end{array}$ & News.bg & $\begin{array}{l}\text { Nuclear } \\
\text { threat }\end{array}$ & $\begin{array}{l}\text { The } \\
\text { Moscow } \\
\text { Times }\end{array}$ & Meduza.io & $\begin{array}{l}\text { Severnye } \\
\text { Novosti }\end{array}$ & $\begin{array}{l}\text { "Sources" } \\
\text { of The } \\
\text { Moscow } \\
\text { Times" }\end{array}$ \\
\hline $\begin{array}{l}\text { https://news.bg/ } \\
\text { world/rusiya- } \\
\text { obvini-sasht-za- } \\
\text { neuspeshniya- } \\
\text { raketen-opit- } \\
\text { kray-seve- } \\
\text { rodvinsk.html }\end{array}$ & News.bg & $\begin{array}{l}\text { Conflict- } \\
\text { ing Rus- } \\
\text { sia }\end{array}$ & $\begin{array}{l}\text { Novaya } \\
\text { Gazeta }\end{array}$ & $\begin{array}{l}\text { Official } \\
\text { represen- } \\
\text { tative of } \\
\text { Russia in } \\
\text { Wien }\end{array}$ & Rosatom & $\begin{array}{l}\text { The Gov- } \\
\text { ernment } \\
\text { of Arkhan- } \\
\text { gelsk } \\
\text { Oblast }\end{array}$ \\
\hline $\begin{array}{l}\text { https://news.bg/ } \\
\text { world/uchen- } \\
\text { burevestnik- } \\
\text { nyama-da- } \\
\text { dade-na-rusiya- } \\
\text { nikakvo-voenno- } \\
\text { prevazhodstvo. } \\
\text { html }\end{array}$ & News.bg & \begin{tabular}{|l|} 
Needless \\
arms \\
race
\end{tabular} & DW & $\begin{array}{l}\text { Russian } \\
\text { Ministry of } \\
\text { Defense }\end{array}$ & & \\
\hline $\begin{array}{l}\text { https://news. } \\
\text { bg/disasters/ } \\
\text { ruskite-vlasti- } \\
\text { priznaha-za- } \\
\text { radioaktivni- } \\
\text { pontoni-na- } \\
\text { brega-kray- } \\
\text { nyonoksa.html }\end{array}$ & News.bg & Disorder & RFE-RL & BBC & $\begin{array}{l}\text { The Gov- } \\
\text { ernment of } \\
\text { Arkhangelsk } \\
\text { Oblast }\end{array}$ & $\begin{array}{l}\text { Belomor- } \\
\text { kanal }\end{array}$ \\
\hline
\end{tabular}


End of the table

\begin{tabular}{|c|c|c|c|c|c|c|}
\hline Link to article & $\begin{array}{c}\text { Media } \\
\text { channel }\end{array}$ & Frame(s) & Source 1 & Source 2 & Source 3 & Source 4 \\
\hline $\begin{array}{l}\text { https://news. } \\
\text { bg/int-politics/ } \\
\text { putin-usavarsh- } \\
\text { enstva-raketa- } \\
\text { ta-ot-nyonoksa- } \\
\text { nezavisimo-ot- } \\
\text { vsichko.html }\end{array}$ & News.bg & $\begin{array}{l}\text { Needless } \\
\text { arms } \\
\text { race, } \\
\text { Putin as } \\
\text { a magnet }\end{array}$ & BBC & Rosatom & $\begin{array}{l}\text { Ministry } \\
\text { of Foreign } \\
\text { Affairs of } \\
\text { Russian } \\
\text { Federation }\end{array}$ & $\begin{array}{l}\text { Russian } \\
\text { Ministry of } \\
\text { Defense }\end{array}$ \\
\hline $\begin{array}{l}\text { https://news. } \\
\text { bg/world/putin- } \\
\text { rusiya-i-kitay- } \\
\text { koordinirat- } \\
\text { mezhdunarod- } \\
\text { nite-si-pozitsii. } \\
\text { html }\end{array}$ & News.bg & $\begin{array}{l}\text { Putin as } \\
\text { a magnet }\end{array}$ & $\begin{array}{l}\text { "The } \\
\text { local } \\
\text { media“ }\end{array}$ & & & \\
\hline $\begin{array}{l}\text { https://news. } \\
\text { bg/world/putin- } \\
\text { sryaza-abe-za- } \\
\text { miren-dogovor- } \\
\text { poiska-kitay- } \\
\text { indiya-i-turtsiya- } \\
\text { vav-formati- } \\
\text { kato-g-7.html }\end{array}$ & News.bg & $\begin{array}{l}\text { Putin as } \\
\text { a magnet }\end{array}$ & Reuters & & & \\
\hline $\begin{array}{l}\text { https://news. } \\
\text { bg/int-politics/ } \\
\text { putin-obeshta- } \\
\text { mashtabna- } \\
\text { razmyana-na- } \\
\text { zatvornitsi-s- } \\
\text { ukrayna.html }\end{array}$ & News.bg & $\begin{array}{l}\text { Putin as } \\
\text { a magnet }\end{array}$ & AFP & & & \\
\hline
\end{tabular}

\section{REFERENCES}

1. Berger P.L., Luckmann T. The Social Construction of Reality: A Treatise in the Sociology of Knowledge. Garden City, Anchor Books, 1966. 240 p.

2. Shoemaker P.J., Reese, S.D. Mediating the message. $2^{\text {nd }}$ ed. White Plains, Longman, 1996. 313 p.

3. Demšar F., Boh T., Južnič $P$. 'Do media reflect reality?: a quantitative study'. International Journal of Innovation and Learning, 2013, vol. 13, no. 2, pp. 140-152. DOI: 10.1504/ IJIL.2013.052284.

4. Nišić V., Plavšić D. The Role of Media in the Construction of Social Reality. Sociological Discourse, 2014, vol. 4, no. 7, pp. 73-81. DOI: 10.7251/SOCEN1407073N.

5. Sambrook R. Delivering trust: impartiality and objectivity in the digital age. University of Oxford, 2012. 42 p.

6. Lohner J., Banjac S., Neverla I. Journalistic Practices, Role Perceptions and Ethics in Democratisation Conflicts: Empirical Findings from Interviews with Journalists in Egypt, Kenya, Serbia and South Africa. University of Leeds, 2016. 82 p.

7. Scheufele D.A. Framing as a Theory of Media Effects. Journal of Communication, 1999, vol. 49, iss. 1, pp. 103-122. DOI: 10.1111/j.1460-2466.1999.tb02784.x. 
8. Fowler R. Language in the News. Discourse and Ideology in the Press. London, Routledge, 1991. $272 \mathrm{p}$.

9. Popova V.O., Balezina E.A. The role of mass media in the formation of mass consciousness. Vestnik Permskogo universiteta. Filosofiya. Psikhologiya. Sotsiologiya $=$ Perm University Herald. Series: Philosophy. Psychology. Sociology, 2015, no. 2 (22), pp. 88-94. (In Russian).

10. Kazakov A. Framing of media texts as a tool for influencing the audience: a review of common interpretations. Izvestiya Saratovskogo universiteta. Novaya seriya. Seriya Cotsiologiya. Politologiya = Izvestiya of Saratov University. New Series. Series: Sociology. Politology, 2014, vol. 14, no. 4, pp. 85-90. (In Russian).

11. Walulya G., Nassanga L.G. Democracy at Stake: Self-Censorship as a Self-Defense Strategy for Journalists. Media and Communication, 2020, vol. 8, iss. 1, pp. 5-14. DOI: 10.17645/mac.v8i1.2512.

12. Chomsky N. Independence of Journalism. Chomsky.info, 2017. Available at: https:// chomsky.info/01072017.

13. Zuhroh N., Rakhmawati N. Clickbait detection: A literature review of the methods used. Register: Jurnal IImiah Teknologi Sistem Informasi, 2019, vol. 6, iss. 1, pp. 1-10. DOI: 10.26594/register.v6i1.1561.

14. Blom J., Hansen K. Click bait: Forward-reference as lure in online news headlines. Journal of Pragmatics, 2015, no. 76, pp. 87-100. DOI: 10.1016/j.pragma.2014.11.010.

15. Himma-Kadakas M. Skill performance of Estonian Online Journalists: Assessment Model for Newsrooms and Research. University of Tartu Press, 2018. 144 p. DOI: 10.13140/ RG.2.2.20285.72163.

16. Fisher C. News Sources and Journalist/Source Interaction. Oxford Encyclopedia of Communication Journalism Studies. Oxford University Press, 2018, pp. 1. DOI: 10.1093/acrefore/9780190228613.013.849.

17. Bodrunova S.S. Framing as a term in political communication studies: how a big idea grew and matured in the media effects theory. Zhurnal politicheskikh issledovanii = Journal of Political Research, 2019, vol. 3. no. 4, pp. 127-141. (In Russian).

18. Atanesyan A.V., Rumachik I.A. (eds). Topical issues in mass information and political communications: a collective monograph. Publishing House of Yerevan State University, 2017. 214 p. (In Russian).

19. Gamson W.A., Croteau D., Hoynes W., Sasson T. Media images and the social construction of reality. Annual Review of Sociology, 1992, vol. 18, pp. 373-393. DOI: 10.1146/ annurev.so.18.080192.002105.

20. Kokurina I.V., Khoretskaya N.Ju. Manipulative potential of frame in russia's image creation in german media. Politicheskaya lingvistika = Political Linguistics Journal, 2018, no. 5, pp. 59-63. DOI: 10.26170/pl18-05-08. (In Russian).

21. Kalugina E.G. Online Media as a Subject of Political Communication: Key Characteristics. Voprosy teorii i praktiki zhurnalistiki = Theoretical and Practical Issues of Journalism, 2017, vol. 6, no. 3, pp. 406-417. DOI: 10.17150/2308-6203.2017.6(3). (In Russian).

22. Franzosi R., Vicari S. What's in a Text? Answers from Frame Analysis and Rhetoric for Measuring Meaning Systems and Argumentative Structures. Rhetorica, 2017, vol. 36, iss. 4, pp. 393-429. DOI: 10.1525/rh.2018.36.4.393.

23. Matthes J. What's in a Frame? A Content Analysis of Media Framing Studies in the World's Leading Communication Journals, 1990-2005. Journalism \& Mass Communication Quarterly, 2009, vol. 86, iss. 2, pp. 349-367. DOI: 10.1177/107769900908600206.

24. Entman R.M. Framing: Toward clarification of a fractured paradigm. Journal of Communication, 1993, vol. 43, iss. 4, pp. 51-58. DOI: 10.1111/j.1460-2466.1993.tb01304.x.

25. Bodrunova S.S. Media effects theory: the need for comprehension and the difficulty in systematizing current research. Vek informatsii = Information Age, 2017, no. 1-2, pp. 77-78. (In Russian).

26. De Vreese C., Boomgaarden $\mathrm{H}$. Valenced news frames and public support for the EU: Linking content analysis and experimental data. Communications, 2003, vol. 3, iss. 4, pp. $361-381$. 
27. Morstatter F., Wu L., Yavanoglu U., Corman S., Liu H. Identifying Framing Bias in Online News. ACM Transactions on Social Computing, 2018, vol. 1, iss. 2, pp. 1-18. DOI: 10.1145/3204948.

28. Schuck A., de Vreese C. Reversed Mobilization in Referendum Campaigns How Positive News Framing Can Mobilize the Skeptics. The International Journal of Press/Politics, 2009, vol. 14, no. 1, pp. 40-66. DOI: 10.1177/1940161208326926.

29. Van Gorp B. The constructionist approach to framing: Bringing culture back in. Journal of Communication, 2007, vol. 57, iss. 1, pp. 60-78. DOI: 10.1111/j.0021-9916.2007.00329.x.

30. Brüggemann M. Between frame setting and frame sending: How journalists contribute to news frames. Communication Theory, 2014, vol. 24, iss. 1, pp. 61-82.

31. Hanitzsch T., Hanusch F., Ramaprasad J., de Beer A.S. (eds). Worlds of Journalism: Journalistic Cultures Around the Globe. New York, Columbia University Press, 2019. 448 p.

32. Boesman J., Berbers A., d'Haenens L., van Gorp B. The news is in the frame: A journalist-centered approach to the frame-building process of the Belgian Syria fighters. Journalism, 2015, vol. 18, iss. 3, pp. 298-316. DOI: 10.1177/1464884915610988.

33. Stecenko N.M. Framing as an Instrument of News Interpretation. Vestnik RUDN. Seriya: Russkii i inostrannye yazyki i metodika ikh prepodavaniya $=$ RUDN Journal of Russian and Foreign Languages Research and Teaching, 2013, no. 2, pp. 38-45. (In Russian).

34. Hjarvard S. The study of international news. In Jensen K.B. (ed.). A Handbook of Media and Communication Research. London, New York, Routledge, 2002, pp. 91-97.

35. Jensen K.B. Media effects. In Jensen K.B. (ed.). A Handbook of Media and Communication Research. London, New York, Routledge, 2002, pp. 138-155.

36. Diggs C. Here's what we know so far about Russia's mysterious radioactive blast. Bellona.org, 2019. Available at: https://bellona.org/news/nuclear-issues/2019-08-heres-whatwe-know-so-far-about-russias-mysterious-radioactive-blast.

37. Vinogradova A., Mashkin C. Unidentified explosive object. Kommersant"= Kommersant, 2019, August 08, pp. 4. Available at: https://www.kommersant.ru/doc/4054822. (In Russian).

38. Bennetts M. Radiation leak after explosion at Nyonoksa missile research site closes major port of Dvina Bay. The Times, 2019, August 08. Available at: https://www.thetimes. co.uk/article/radiation-leak-after-explosion-at-nyonoksa-missile-research-site-closes-majorport-at-dvina-bay-gv5bcn0p3.

39. Skorodumov Yu. The ban on navigation of ships at Nyonoksa was extended until early February. 29.ru. Available at: https://29.ru/text/transport/2020/01/10/66437524. (In Russian).

40. Roth A., Sabbagh D. Russia indicates rocket engine exploded in test of mini nuclear reactor. The Guardian, 2019. Available at: https://www.theguardian.com/world/2019/aug/12/ russia-indicates-rocket-engine-exploded-in-test-of-mini-nuclear-reactor.

41. Hiietamm A. ÕNNETUS ÕNNETUSE OTSA: Vene mereväepolügoonil hukkus seitse inimest. Õhtuleht, 2019. Available at: https://www.ohtuleht.ee/973039/onnetus-onnetuseotsa-vene-merevaepolugoonil-hukkus-seitse-inimest. (In Estonian).

42. Kressa K. Arhangelskis süttis järjekordne Vene sõjaline objekt, hukkus kaks inimest. DELFI, 2019. Available at: https://www.delfi.ee/news/paevauudised/valismaa/arhangelskissuttis-jarjekordne-vene-sojaline-objekt-hukkus-kaks-inimest?id=87077675. (In Estonian).

43. Makar Yu. Roshydromet reported a 16-fold jump in radiation levels in Severodvinsk. DW, 2019. Available at: https://p.dw.com/p/3Np4k. (In Russian).

44. Astafurova K., Burmistrova S. Roshydromet announced a jump in the radiation level in Severodvinsk on the day of the explosion. RBK, 2019. Available at: https://www.rbc.ru/soci ety/13/08/2019/5d526bdb9a7947190f6c72a6. (In Russian).

45. Semetko H., Valkenburg P.M. Framing European politics: A content analysis of press and television news. Journal of Communication, 2000, vol. 50, iss. 2, pp. 93-109. DOI: 10.1111/j.1460-2466.2000.tb02843.x.

46. Viirand L. Putini sõnul tervitaks Venemaa G8 taastamist. ERR, 2019. Available at: https://www.err.ee/977547/putini-sonul-tervitaks-venemaa-g8-taastamist. (In Estonian).

47. Laugen L. Putin: läbirääkimised Vene-Ukraina ulatusliku vangide vahetuse üle on lõpule jõudmas. DELFI, 2019. Available at: https://www.delfi.ee/news/paevauudised/ valismaa/putin-labiraakimised-vene-ukraina-ulatusliku-vangide-vahetuse-ule-on-lopulejoudmas?id=87344871. (In Estonian). 
48. Hiietamm A. PUTIN: vangide vahetus Ukrainaga tuleb mastaapne. Õhtuleht, 2019. Available at: https://www.ohtuleht.ee/975866/putin-vangide-vahetus-ukrainaga-tuleb-mastaapne. (In Estonian).

49. Mishchenko O. Putin announced the imminent exchange of prisoners between Russia and Ukraine. DW, 2019. Available at: https://p.dw.com/p/3P2ev. (In Russian).

50. Bushuev M. Explosion near Severodvinsk: "Why do we need the Burevestnik after all?"DW, 2019. Available at: https://p.dw.com/p/30i7Y. (In Russian).

51. Ilyshina M. Russian officials blame cesium exposure on 'Fukushima crabs'. CNN, 2019. Available at: https://edition.cnn.com/2019/08/24/europe/russia-fukushima-crabs-int// index.html.

52. Bartholomé G., Lecheler S., de Vreese C. Manufacturing Conflict? How Journalists Intervene in the Conflict Frame Building Process. The International Journal of Press/Politics, 2015, vol. 20, iss. 4, pp. 438-457. DOI: 10.1177/1940161215595514.

53. Preobrazhenskii I. Commentary: The accident near Arkhangelsk is the media Chernobyl of the Russian authorities. DW, 2019. Available at: https://p.dw.com/p/3Nn3o. (In Russian).

54. Viirand L. Putini sõnul tervitaks Venemaa G8 taastamist. ERR, 2019. Available at: https://www.err.ee/977547/putini-sonul-tervitaks-venemaa-g8-taastamist. (In Estonian).

55. Miller M., Vaccari C. Digital Threats to Democracy: Comparative Lessons and Possible Remedies. The International Journal of Press/Politics, 2020, vol. 25, iss. 3, pp. 333-356. DOI: $10.1177 / 1940161220922323$.

56. Mylnikov P. Putin commented on youth participation in Moscow protests. DW, 2019. Available at: https://p.dw.com/p/3P50w. (In Russian).

\section{ДЛЯ ЦИТИРОВАНИЯ}

Кремез М. Фрейминг России в интернет-СМИ Эстонии, Германии и Болгарии: освещение двух конкретных событий / М. Кремез, Р. Кыутс-Клемм. - DOI: 10.17150/23086203.2021.10(1).109-129 // Вопросы теории и практики журналистики. - 2021. - Т. 10, № 1. - C. 109-129.

\section{FOR CITATION}

Kremez M., Kõuts-Klemm R. Framing Russia in the Estonian, German, and Bulgarian Online Media: Coverage of Two Concrete Events. Voprosy teorii i praktiki zhurnalistiki $=$ Theoretical and Practical Issues of Journalism, 2021, vol. 10, no. 1, pp. 109-129. DOI: 10.17150/23086203.2021.10(1).109-129. 